\title{
IMPLEMENTASI BELA NEGARA \\ DI LINGKUNGAN MAHASISWA \\ STABN SRIWIJAYA TANGERANG BANTEN
}

\author{
Muawanah \\ STABN Sriwijaya \\ punyamuawanah@gmail.com
}

\begin{abstract}
Country's defense is the attitude and actions of citizens which is based with a sense of love of the fatherland, and awareness State, convinced that Pancasila was the ideology of the nation and the country and willing to sacrifice in the face of any threats, challenges, obstacles and distractions, whether it comes from within and from outside that could endanger the survival of the nation and the State, territorial integrity and of the sublime values of Pancasila and the 1945 Constitution. The College was established in the framework of the intellectual life of the nation aimed at scoring cadres cadres generations of leaders of the Nations are certainly expected to create educational system characteristic as the implementation of the country's defense posture. Students are the intellectuals, the critical and have a strong passion in defense of the country. The student spirit is the spirit of escorting and supervising the survival of the nation and the State, always embedded in the soul of every student. Students always implement two functions, i.e. into a society that has a specific field of academic ability, as well as a student-community and has a great sense of responsibility towards the future of the nation and the State. One of them is The Sriwijaya Buddhist State College students
\end{abstract}

Keywords: Country's defense, college students, The Sriwijaya Buddhist State College.

\section{Pendahuluan}

Bangsa Indonesia saat ini sedang menapaki dan melanjutkan pembangunan di segala sektor. Belum bisa dipastikan resiko atau ganguan yang akan dihadapi. Tetapi satu hal yang sudah pasti ialah adanya derajat ketidakpastian dan semakin tingginya kompleksitas permasalahan. Menghadapi hal tersebut, yang diperlukan adalah tidak hanya merapatkan barisan di antara pelaku-pelaku pembangunan, tetapi juga perlu upaya peningkatan pengertian dan kesadaran di masyarakat luas akan perannya dalam wujud bela negara. Sudah menjadi kesadaran bersama, bahwa berhasil atau tidaknya suatu program sangat ditentukan oleh unsur kualitas sumber daya manusia.

Berbagai kenyataan menunjukkan bahwa keunggulan kompetitif suatu bangsa terhadap bangsa lain tidak lagi semata-mata ditentukan oleh berlimpahnya kekayaan sumber daya alamiah, melainkan ditentukan oleh kualitas sumber daya manusianya, dalam bentuk kualitas pribadi, kualitas karya maupun kualitas semangat kebangsaannya. Oleh karena itu, mudah 
untuk dipahami betapa sentralnya kedudukan pendidikan dan pelatihan bagi penyiapan dan peningkatan kemampuan sumber daya manusia. Kemampuan bangsa yang dibangun berlandaskan pembinaan kualitas sumber daya manusia diharapkan akan menghasilkan ketangguhan bangsa dalam semua aspek kehidupan berbangsa dan bernegara yang sekaligus juga akan membawa serta ke arah peningkatan keuletan masyarakat dan bangsa dalam menghadapi berbagai tantangan maupun ancaman baik yang datang dari dalam maupun dari luar negeri.

Mahasiswa dapat dikatakan sebuah komunitas unik yang berada di masyarakat, dengan kesempatan dan kelebihan yang dimilikinya, mahasiswa mampu berada sedikit di atas masyarakat. Mahasiswa juga belum tercekoki oleh kepentingan-kepentingan suatu golongan, organisasi masyarakat, partai politik, dan lain sebagainya.

Berdasarkan berbagai potensi dan kesempatan yang dimiliki oleh mahasiswa, tidak sepantasnyalah bila mahasiswa hanya mementingkan kebutuhan dirinya sendiri tanpa memberikan kontribusi terhadap bangsa dan negaranya. Mahasiswa itu sudah bukan siswa yang tugasnya hanya belajar, bukan pula rakyat, bukan pula pemerintah. Mahasiswa memiliki tempat tersendiri di lingkungan masyarakat, namun bukan berarti memisahkan diri dari masyarakat. Oleh karena itu perlu dirumuskan perihal peran, fungsi, dan posisi mahasiswa untuk menentukan arah perjuangan dan kontribusi mahasiswa tersebut terhadap bangsa dan negaranya.

Bela negara tidaklah berarti suatu kegiatan "memanggul senjata" atau yang berbau "militerisme" belaka, melainkan segala aspek kehidupan yang terkait dengan terjaganya kedaulatan Negara Kesatuan Republik Indonesia.

Berdasarkan Pasal 30 UUD 1945, bela negara merupakan hak dan kewajiban setiap warga negara Republik Indonesia. Bela negara adalah upaya setiap warga negara untuk mempertahankan Republik Indonesia terhadap ancaman baik dari luar maupun dalam negeri.

Kesadaran bela negara merupakan satu hal yang essensial dan harus dimiliki oleh setiap warga negara Indonesia (WNI), sebagai wujud penunaian hak dan kewajibannya dalam upaya bela negara. Kesadaran bela negara menjadi modal dasar sekaligus kekuatan bangsa, dalam rangka menjaga keutuhan, kedaulatan serta kelangsungan hidup bangsa dan negara Indonesia.

Oleh karena itu, mahasiswa sebagai bagian masyarakat memiliki kewajiban untuk bela negara. Begitu pula mahasiswa di STABN Sriwijaya Tangerang Banten.

\section{Pembahasan \\ Bela Negara}

Konsep bela negara dapat diartikan secara fisik dan non-fisik, secara fisik dengan mengangkat senjata menghadapi serangan atau agresi musuh, secara non-fisik dapat didefinisikan sebagai segala upaya untuk 
mempertahankan negara dengan cara meningkatkan rasa nasionalisme, yakni kesadaran berbangsa dan bernegara, menanamkan kecintaan terhadap tanah air, serta berperan aktif dalam memajukan bangsa dan negara.

Menurut wikipedia bahasa Indonesia, bela negara adalah sebuah konsep yang disusun oleh perangkat perundangan dan petinggi suatu negara tentang patriotisme seseorang, suatu kelompok atau seluruh komponen dari suatu negara dalam kepentingan mempertahankan eksistensi negara tersebut.

Bela negara tidaklah berarti suatu kegiatan "memanggul senjata" atau yang berbau "militerisme" belaka, melainkan segala sapek kehidupan yang terkait dengan terjaganya kedaulatan Negara Kesatuan Republik Indonesia.

Unsur dasar bela negara yang dianut oleh bangsa Indonesia adalah sebagai berikut:

1. Cinta tanah air

2. Kesadaran berbangsa dan bernegara

3. Yakin akan Pancasila sebagai ideologi negara

4. Rela berkorban untuk bangsa dan negara

5. Memiliki kemampuan awal bela negara.

Beberapa dasar hukum dan peraturan tentang wajib bela negara di Indonesia adalah sebagai berikut:

1. Tap MPR No. VI Tahun 1973 tentang Konsep Wawasan Nusantara dan Keamanan Nasional

2. Undang-undang No. 29 Tahun 1954 tentang Pokok-pokok Perlawanan Rakyat

3. Undang-undang No. 20 Tahun 1982 tentang Ketentuan Pokok Hankam Negara RI diubah oleh Undang-Undang Nomor 1 Tahun 1988

4. Tap MPR No. VI Tahun 2000 tentang Pemisahan TNI dengan POLRI

5. Tap MPR No. VII Tahun 2000 tentang Peranan TNI dan POLRI

6. Amandemen UUD 1945 Pasal 30 ayat 1-5 dan Pasal 27 ayat 3

7. Undang-Undang No. 3 Tahun 2002 tentang Pertahanan Negara. Alasan bela negara adalah sebagai berikut:

1. Menghormati dan menghargai para pahlawan yang telah berjuang merebut kemerdekaan;

2. Ingin memajukan negara;

3. Mempertahankan negara jangan sampai dijajah kembali;

4. Meningkatkan harkat dan martabat bangsa di mata dunia internasional.

Bentuk-bentuk bela negara yang dapat dilakukan antara lain:

1. Secara fisik

Segala upaya untuk mempertahankan kedaulatan negara dengan cara berpartisipasi secara langsung dalam upaya pembelaan negara (TNI mengangkat senjata dan rakyat berkarya nyata dalam proses pembangunan).

2. Secara non fisik

Segala upaya untuk mempertahankan NKRI dengan cara meningkatkan kesadaran berbangsa dan bernegara, menanamkan kecintaan 
pada tanah air serta berperan aktif dalam upaya memajukan bangsa sesuai dengan profesi dan kemampuannya.

Wujud bela negara adalah sebagai berikut:

1. Lingkungan keluarga: memahami hak dan kewajiban dalam keluarga, menjaga keutuhan dan keharmonisan keluarga, demokratis, menjaga nama baik keluarga dan lain-lain.

2. Lingkungan sekolah: patuh pada aturan sekolah, berkata dan bersikap baik, bertanggung jawab atas tugas yang diberikan, tidak ikut tawuran, dan lain-lain.

3. Lingkungan masyarakat: aktif dalam kegiatan masyarakat, rela berkorban untuk kepentingan masyarakat.

4. Lingkungan berbangsa dan bernegara; menghormati jasa pahlawan, berani mengemukakan pendapat, melestarikan adat dan budaya asli daerah.

Dari unsur yang ada tersebut, bisa disebutkan mengenai beberapa hal yang menjadi contoh proses pembelaan negara. Beberapa contoh tersebut di antaranya adalah:

1. Kesadaran untuk melestarikan kekayaan budaya, terutama kebudayaan daerah yang beraneka ragam. Sehingga hal ini bisa mencegah adanya pengakuan dari negara lain yang menyebutkan kekayaan daerah Indonesia sebagai hasil kebudayaan asli mereka.

2. Untuk para pelajar, bisa diwujudkan dengan sikap rajin belajar. Sehingga pada nantinya dapat memunculkan sumber daya manusia yang cerdas serta mampu menyaring berbagai macam informasi yang berasal dari pihak. Dengan demikian, masyarakat tidak mudah terpengaruh dengan adanya informasi yang belum dapat dipertanggungjawabkan dari berbagai pihak.

3. Adanya kepatuhan dan ketaatan pada hukum yang berlaku. Hal ini sebagai perwujudan rasa cinta tanah air dan bela bangsa. Karena dengan taat pada hukum yang berlaku dapat menciptakan keamanan dan ketentraman bagi lingkungan serta mewujudkan rasa keadilan di tengah masyarakat.

4. Meninggalkan korupsi. Korupsi merupakan penyakit berbahaya karena merampas hak warga negara untuk mendapatkan kesejahteraan. Dengan meninggalkan korupsi, dapat membantu masyarakat dan bangsa dalam meningkatkan kualitas kehidupan.

\section{Pentingnya Bela Negara}

Muncul pertanyaan mengapa warga negara wajib melakukan bela negara? Bukankah tugas mempertahankan negara sudah diamanakan kepada aparat keamanan dalam hal ini melalui fungsi Tentara Nasional Indonesia. Ada beberapa hal yang menjadi landasan mengapa proses bela negara ini wajib dilakukan oleh seluruh warga negara. Di antaranya adalah: 
1. Keterbatasan aparat TNI. Sehingga tidak semua wilayah di Indonesia bisa dijaga oleh aparat TNI. Dengan peran serta masyarakat, maka akan terjadi sinergi antara warga dan TNI dalam proses penjagaan kedaulatan bangsa.

2. Wujud rasa terimakasih warga atas segala kenikmatan yang didapat selama menjadi penduduk suatu bangsa.

3. Menciptakan ketentraman dan keamanan lingkungan dari gangguan pihak asing yang ingin merusak tatanan budaya bangsa.

4. Melestarikan kekayaan bangsa dari jarahan bangsa asing.

\section{Mahasiswa}

Mahasiswa adalah sebutan bagi orang yang sedang menempuh pendidikan tinggi di sebuah perguruan tinggi yang terdiri atas sekolah tinggi, akademi, dan yang paling umum adalah universitas. Sepanjang sejarah, mahasiswa diberbagai negara mengambil peran penting dalam sejarah suatu negara. Misalnya, di Indonesia pada Mei 1998, ratusan ribu mahasiswa berhasil mendesak Presiden Soeharto untuk mundur dari jabatannya.

Mahasiswa dapat dikatakan sebuah komunitas unik yang berada di masyarakat, dengan kesempatan dan kelebihan yang dimilikinya, mahasiswa mampu berada sedikit di atas masyarakat. Mahasiswa juga belum tercekoki oleh kepentingan-kepentingan suatu golongan, ormas, parpol, dan lain sebagainya.

Mahasiswa adalah seseorang yang potensial dalam memahami perubahan dan perkembangan di dunia pendidikan dan lingkungan masyarakat. Yang memiliki posisi dan peran sebagai agent of change, social controler, dan the future leader. Mahasiswa sebagai bagian dari kaum muda dalam tatanan masyarakat yang mau tidak mau pasti terlibat langsung dalam tiap fenomena sosial, harus mampu mengimplementasikan kemampuan keilmuannya dalam akselerasi perubahan keumatan ke arah berkeadaban.

Berdasarkan berbagai potensi dan kesempatan yang dimiliki oleh mahasiswa, tidak sepantasnyalah bila mahasiswa hanya mementingkan kebutuhan dirinya sendiri tanpa memberikan kontribusi terhadap bangsa dan negaranya. Mahasiswa itu sudah bukan siswa yang tugasnya hanya belajar, bukan pula rakyat, bukan pula pemerintah. Mahasiswa memiliki tempat tersendiri di lingkungan masyarakat, namun bukan berarti memisahkan diri dari masyarakat. Oleh karena itu perlu dirumuskan perihal peran, fungsi, dan posisi mahasiswa untuk menentukan arah perjuangan dan kontribusi mahasiswa tersebut.

Adapun peran, fungsi, dan posisi mahasiswa dalam masyarakat adalah sebagai berikut:

1. Agent OfChange (Generasi Perubahan)

Mahasiswa sebagai agen dari suatu perubahan. Artinya jika ada sesuatu yang terjadi di lingkungan sekitar dan itu salah, mahasiswa dituntut untuk merubahnya sesuai dengan harapan sesungguhnya. Dengan harapan bahwa 
suatu hari mahasiswa dapat menggunakan disiplin ilmunya dalam membantu pembangunan Indonesia untuk menjadi lebih baik ke depannya.

2. Social Control (Generasi Pengontrol)

Sebagai generasi pengontrol seorang mahasiswa diharapkan mampu mengendalikan keadaan sosial yang ada di lingkungan sekitar. Jadi, selain pintar dalam bidang akademis, mahasiswa juga harus pintar dalam bersosialisasi dan memiliki kepekaan dengan lingkungan. Mahasiswa diupayakan agar mampu mengkritik, memberi saran dan memberi solusi jika keadaan sosial bangsa sudah tidak sesuai dengan cita-cita dan tujuan bangsa. Mahasiswa harus memiliki kepekaan, kepedulian, dan kontribusi nyata terhadap masyarakat sekitar tentang kondisi yang teraktual.

3. Iron Stock (Generasi Penerus)

Sebagai tulang punggung bangsa di masa depan, mahasiswa diharapkan menjadi manusia-manusia tangguh yang memiliki kemampuan dan akhlak mulia yang nantinya dapat menggantikan generasi-generasi sebelumnya di pemerintahan kelak. Intinya mahasiswa itu merupakan aset, cadangan, harapan bangsa untuk masa depan bangsa Indonesia.

4. Moral Force (Gerakan Moral)

Mahasiswa sebagai penjaga stabilitas lingkungan masyarakat, diwajibkan untuk menjaga moral-moral yang ada. Bila di lingkungan sekitar terjadi hal-hal yang menyimpamg dari norma yang ada, maka mahasiswa dituntut untuk merubah dan meluruskan kembali sesuai dengan apa yang diharapkan. Mahasiswa sendiripun harus punya moral yang baik agar bisa menjadi contoh bagi masyarakat dan juga harus bisa merubah ke arah yang lebih baik jika moral bangsa sudah sangat buruk, baik melalui kritik secara diplomatis ataupun aksi.

5. Guardian of Value (Penjaga nilai-nilai)

Mahasiswa sebagai "guardian of value" artinya penjaga nilai-nilai. Sesuai dengan artinya mahasiswa berperan sebagai penjaga nilai-nilai, nilai-nilai tersebut bukanlah nilai-nilai yang negatif melainkan nilai-nilai yang positif. Tugas perguruan tinggi adalah membentuk insan akademis, yang selanjutnya hal tersebut akan menjadi sebuah fungsi bagi mahasiswa itu sendiri. Insan akademis itu sendiri memiliki dua ciri yaitu : memiliki sense of crisis dan selalu mengembangkan dirinya.

Insan akademis harus memiliki sense of crisis yaitu peka dan kritis terhadap masalah-masalah yang terjadi di sekitarnya saat ini. Hal ini akan tumbuh dengan sendirinya bila mahasiswa itu mengikuti watak ilmu, yaitu selalu mencari pembenaran-pembenaran ilmiah. Dengan mengikuti watak ilmu tersebut maka mahasiswa diharapkan dapat memahami berbagai masalah yang terjadi dan terlebih lagi menemukan solusi-solusi yang tepat untuk menyelesaikannya.

Insan akademis harus selalu mengembangkan dirinya sehingga mereka bisa menjadi generasi yang tanggap dan mampu menghadapi tantangan masa depan. Mahasiswa dengan segala kelebihan dan potensinya tentu saja tidak 
bisa disamakan dengan rakyat dalam hal perjuangan dan kontribusi terhadap bangsa. Mahasiswa pun masih tergolong kaum idealis, di mana keyakinan dan pemikiran mereka belum dipengaruhi oleh partai politik, organisasi masyarakat, dan lain sebagainya. Sehingga mahasiswa dapat dikatakan memiliki posisi di antara masyarakat dan pemerintah.

Mahasiswa dalam hal hubungan masyarakat ke pemerintah dapat berperan sebagai kontrol politik, yaitu mengawasi dan membahas segala pengambilan keputusan beserta keputusan-keputusan yang telah dihasilkan sebelumnya. Mahasiswa pun dapat berperan sebagai penyampai aspirasi rakyat, dengan melakukan interaksi sosial dengan masyarakat dilanjutkan dengan analisis masalah yang tepat maka diharapkan mahasiswa mampu menyampaikan realita yang terjadi di masyarakat beserta solusi ilmiah dan bertanggung jawab dalam menjawab berbagai masalah yang terjadi di masyarakat.

Mahasiswa dalam hal hubungan pemerintah ke masyarakat dapat berperan sebagai penyambung lidah pemerintah. Mahasiswa diharapkan mampu membantu mensosialisasikan berbagai kebijakan yang diambil oleh pemerintah. Tak jarang kebijakan-kebijakan pemerintah mengandung banyak salah pengertian dari masyarakat, oleh karena itu tugas mahasiswalah yang harus "menerjemahkan" maksud dan tujuan berbagai kebijakan kontroversial tersebut agar mudah dimengerti masyarakat.

Posisi mahasiswa cukuplah rentan, sebab mahasiswa berdiri di antara idealisme dan realita. Tak jarang mahasiswa berat sebelah, saat mahasiswa membela idealisme ternyata mahasiswa melihat realita masyarakat yang semakin buruk. Saat mahasiswa berpihak pada realita, ternyata mahasiswa secara tak sadar sudah meninggalkan idealisme mahasiswa dan juga kadang sudah meninggalkan watak ilmu yang seharusnya mahasiswa miliki. Contoh kasusnya yang paling gampang adalah saat terjadi penaikkan harga BBM.

Perjuangan-perjuangan yang dilakukan mahasiswa kini sudah kehilangan esensinya, sehingga masyarakat sudah tidak menganggapnya suatu harapan pembaruan lagi. Sedangkan golongan-golongan atas seperti pengusaha, dokter, dan lain sebagainya merasa sudah tidak ada lagi kesamaan gerakan. Perjuangan mahasiswa kini sudah berdiri sendiri dan tidak lagi "satu nafas" bersama rakyat.

\section{STABN Sriwijaya Tangerang Banten}

STABN Sriwijaya Tangerang Banten adalah salah satu perguruan tinggi agama Buddha dengan status instansi pemerintah di bawah naungan Kementerian Agama Republik Indonesia yang ditetapkan berdasarkan Peraturan Presiden RI Nomor 76 Tahun 2005 tanggal 29 Desember 2005. Adapun tugas dan fungsi STABN Sriwijaya Tangerang Banten sesuai dengan Tridharma Perguruan Tinggi, yaitu:

1. Menjadi pusat penyelenggaraan pendidikan formal keagamaan Buddha.

2. Melaksanakan penelitian. 
3. Melaksanakan pengabdian kepada masyarakat.

Visi STABN Sriwijaya Tangerang Banten adalah "Menjadi lembaga pendidikan terkemuka tahun 2020 dengan mengedepankan kearifan lokal". Visi tersebut ditunjang oleh misi STABN Sriwijaya Tangerang Banten, yaitu:

1. Mewujudkan sumber daya manusia yang unggul dan terkemuka;

2. Memperluas jaringan kerja sama dalam bidang Tridharma Perguruan Tinggi;

3. Memenuhi sarana dan prasarana dalam mewujudkan visi;

4. Mewujudkan sistem administrasi yang akuntabel dan transparan.

\section{Implementasi Bela Negara di Lingkungan Mahasiswa STABN Sriwijaya Tangerang Banten}

STABN Sriwijaya Tangerang Banten adalah salah satu perguruan tinggi agama Buddha dengan status instansi pemerintah di bawah naungan Kementerian Agama Republik Indonesia, menghasilkan mahasiswa yang memiliki kemampuan di bidang Agama Buddha yang nantinya menjadi guru Agama Buddha dan Penyuluh Agama Buddha.

STABN Sriwijaya Tangerang merupakan salah satu lembaga pendidikan. Sebagai lembaga pendidikan nasional mempunyai peran yang sangat besar dalam bela negara. Peran pendidikan sangat efektif menimbulkan rasa memiliki dan keinginan untuk mengembangkan kekayaan nasional dari masing-masing budaya lokal. Jadi salah satu upaya untuk mengembalikan dan mengembangkan identitas nasional adalah melalui bidang pendidikan. Identitas nasional yang dikembangkan melalui pendidikan diharapkan memberi harapan positif bagi kemajuan bangsa untuk mempertahankan karakteristiknya sebagai sebuah bangsa yang beradab.

Mahasiswa STABN Sriwijaya Tangerang merupakan bagian dari warga negara yang memiliki kewajiban untuk melakukan bela negara yang disesuaikan dengan perannya sebagai agen perubahan dan agen pembangunan. Mahasiswa STABN Sriwijaya Tangerang sebagai agen perubahan, harus melakukan perubahan karena perubahan itu sendiri harga mutlak dan pasti terjadi, baik itu perubahan pada tatanan masyarakat yang bersifat materialistik maupun perubahan ideologi atau nilai. Adapun Mahasiswa STABN Sriwijaya sebagai agen pembangunan, harus memiliki peran dalam membangun bangsa baik segi politik, ekonomi, sosial, budaya, hukum dan hak asasi manusia.

Mahasiswa STABN Sriwijaya Tangerang sebagai kader muda bangsa, menjadi bagian utama yang harus mendapat penanaman bela negara, karena kenyataannya potensi ancaman yang dihadapi Negara Kesatuan Republik Indonesia tampaknya akan lebih banyak muncul dari dalam negeri, yakni disintegrasi bangsa, keresahan sosial karena ketimpangan ekonomi dan pelangaran HAM, upaya penggantian Pancasila, dan potensi konflik antar kelompok atau golongan. 
Kesadaran bela negara merupakan sikap moral dan implementasi profesionalisme, sehingga dalam aktualisasinya mampu menjadikannya sebagai unsur utama kekuatan bangsa dalam menghadapi ancaman militer. Di STABN Sriwijaya Tangerang, salah satu upaya mengimplementasikan bela negara adalah melalui mata kuliah Pendidikan Pancasila dan Pendidikan Kewarganegaraan.

Pendidikan Pancasila dan Pendidikan Kewarganegaraan yang diberikan kepada mahasiswa merupakan upaya untuk menumbuhkan sikap perilaku bela negara yang mencakup pembangunan sikap moral dan watak bangsa serta pendidikan politik kebangsaan. Pembangunan sikap moral dan watak bangsa memberikan ikatan dasar yang dapat mendukung ide kewarganegaraan tersebut, memberikan arahan sikap dan perilaku karena dapat memberikan kerangka orientasi nilai. Orientasi nilai yang dilandasi nilai-nilai komunal (nilai-nilai kebangsaan) yang disepakati merupakan ikatan maya, yang jika tertanam dalam sanubari tiap warga negara justru dapat mengikat kuat karena menjadi pedoman perilaku dalam kehidupan bermasyarakat, berbangsa dan bernegara.

Selain itu, upaya lain untuk mengimplementasikan bela negara di lingkungan mahasiswa STABN Sriwijaya Tangerang adalah melalui unit kegiatan mahasiswa, diantaranya UKM Seni, UKM Olahraga, dan UKM Kerohanian.

Melalui UKM Seni, diharapkan mahasiswa STABN Sriwijaya Tangerang akan memiliki rasa kecintaan terhadap budaya bangsa dengan selalu mengembangkan dan melestarikan seni budaya Indonesia melalui pementasan baik berskala nasional maupun internasional.

Melalui UKM Olahraga, diharapkan mahasiswa STABN Sriwijaya Tangerang akan memiliki fisik dan mental yang kuat untuk selalu membela bangsa dan negaranya dari ancaman yang bisa merusak baik yang datang dari dalam maupun dari luar negeri.

Sedangkan melalui UKM Kerohanian, diharapkan mahasiswa STABN Sriwijaya Tangerang akan memiliki karakter (budi pekerti plus), sehingga akan tertanam dengan baik dalam dirinya, yang pada gilirannya kelak akan menciptakan pribadi yang berkarakter unggul dan memiliki integritas. Jika ini dapat diterapkan, niscaya permasalahan bangsa akan dapat terselesaikan satu persatu secara bertahap dan kesadaran bela negara akan tumbuh dengan sendirinya.

Adapun upaya-upaya lain implementasi bela negara yang dapat dilakukan di lingkungan mahasiswa STABN Sriwijaya Tangerang antara lain adalah menyiapkan diri pada setiap dosen untuk menyisipkan pendidikan kesadaran bela negara secara sistematik dan berkelanjutan dalam setiap pertemuan di ruang kuliah. Secara Institusional, ruang-ruang kegiatan yang terarah ke peningkatan kesadaran bela negara terus ditingkatkan, diantaranya dengan membuka peluang mereka untuk bersosialisasi dalam berbagai kegiatan non kurikuler, baik dalam bidang seni dan budaya maupun 
keolahragaan. Berbagai pelatihan khusus yang diselenggarakan, seperti latihan kepemimpinan hendaknya mendapatkan perhatian khusus, karena media ini dapat menyiapkan mahasiswa yang berminat secara khusus mendapatkan pendidikan yang utuh dan tepat, sehingga mereka dapat menjadi kader-kader pemimpin dalam menyiapkan rekan-rekannya maupun adik-adiknya meningkatkan kesadaran bela negara. Kuliah-kuliah umum dengan materi untuk meningkatkan kesadaran bela negara, yang dibawakan oleh para tokoh/praktisi yang mumpuni tentunya merupakan hal penting yang perlu diselenggarakan secara teratur. Cerita-cerita perjuangan, baik itu tentang pahlawan-pahlawan negara, maupun tokoh-tokoh dalam pewayangan, hendaknya dapat disebarluaskan dalam bentuk yang menarik, baik bagi kanak-kanak maupun remaja dan orang dewasa, mengalahkan cerita-cerita yang berasal dari negara lain dan juga komik-komik hiburan belaka.

Dapat disadari bahwa untuk melaksanakan upaya-upaya menumbuhkan kesadaran bela negara bukanlah hal yang mudah. Namun demikian secara mendasar perlu melakukan upaya membangun integritas bangsa Indonesia, khususnya para pemuda dalam hal ini khususnya mahasiswa sebagai harapan bangsa ini. Untuk itu perlu dperhatikan bahwa integritas dapat dibangun melalui pendidikan karakter yang tepat. Dalam hal ini di lingkungan mahasiswa STABN Sriwijaya pendidikan karakter di perkuat dengan kegiatan-kegiatan kerohanian.

Pendidikan karakter (budi pekerti plus) hendaknya diberikan sejak masa kanak-kanak, sehingga akan tertanam dengan baik dalam dirinya, yang pada gilirannya kelak akan menciptakan pribadi yang berkarakter unggul dan memiliki integritas. Jika ini dapat diterapkan kepada seluruh bangsa Indonesia, niscaya permasalahan bangsa akan dapat terselesaikan satu persatu secara bertahap dan kesadaran bela negara akan tumbuh dengan sendirinya. Tantangan bagi kita adalah bagaimana menerapkan pendidikan karakter secara sinergis di keluarga dan di lingkungan pendidikan formal.

Pada akhirnya dengan adanya implementasi bela negara di lingkungan mahasiswa STABN Sriwijaya Tangerang Banten ini, maka diharapkan dapat:

1. Menumbuhkan rasa cinta tanah air serta kesadaran berbangsa dan bernegara;

2. Meyakini Pancasila sebagai ideologi negara;

3. Menumbuhkan jiwa rela berkorban bagi bangsa dan negara;

4. Membentuk disiplin diri, disiplin kelompok, dan pada akhirnya disiplin nasional;

5. Mengamalkan 8 nilai konservasi (inspiratif, humanis, peduli, inovatif, kreatif, sportif, jujur, dan adil);

6. Memiliki etos belajar dan etos kerja yang tinggi;

7. Menjaga lingkungan yang bersih, indah, dan sehat; 
8. Mempersiapkan diri dalam menghadapi ancaman, penyalahgunaan narkoba, paham radikalisme, bencana alam, serta penyebaran penyakit menular; dan

9. Mencintai karya bangsa sendiri, menghargai sesama dan menumbuhkan semangat gotong royong.

Semoga cita-cita untuk membangun bangsa dan mempertahankan kedaulatan Negara Kesatuan Republik Indonesia melalui implementasi bela negara di lingkungan mahasiswa STABN Sriwijaya Tangerang Banten selalu mendapat limpahan rahmat dan lindungan Tuhan Yang Maha Esa.

\section{Penutup}

Setiap warga negara memiliki hak dan kewajiban untuk melakukan bela negara. Bela negara adalah sikap dan tindakan warga negara yang dilandasi rasa cinta tanah air, kesadaran berbangsa dan bernegara, keyakinan Pancasila sebagai ideologi bangsa dan negara, kerelaan berkorban guna menghadapi setiap ancaman, tantangan, hambatan dan gangguan, baik yang datang dari dalam maupun dari luar yang membahayakan kelangsungan hidup bangsa dan Negara, keutuhan wilayah, dan nilai - nilai luhur Pancasila dan Undang Undang Dasar 1945. Pengertian ini memberi kesempatan yang seluas luasnya kepada setiap warga negara untuk melakuan aktifitas bela negara.

Mahasiswa merupakan salah satu bagian dari masyarakat dan pemerintah yang ikut bagian dari bela negara. Wadah penyaluran potensi mahasiswa-mahasiswa untuk ikut serta dalam bela negara melalui Pendidikan Pancasila dan Pendidikan Kewarganegaraan serta menyisipkan pendidikan kesadaran bela Negara secara sistematik dan berkelanjutan dalam setiap pertemuan di ruang kuliah sehingga menimbulkan rasa kesadaran bela negara dengan semangat, disiplin dan jiwa nasionalisme yang tinggi.

Upaya dan tugas membela negara, upaya menjaga keselamatan dan keutuhan bangsa dan negara ini, bukanlah semata-mata tugas Pemerintah dan TNI semata-mata, melainkan merupakan tugas dari seluruh bangsa dan rakyat Indonesia sebagaimana diamanatkan dalam Pasal 30 UUD 1945. Bela negara ini juga merupakan tugas dan tanggung jawab mahasiswa STABN Sriwijaya Tangerang Banten.

Bela negara sejatinya menjadi salah satu identitas nasionalisme warga negara tanpa terkecuali, oleh karena itu masyarakat hendaknya terlibat aktif serta mengambil peran sesuai dengan kedudukannya masing-masing guna mewujudkan identitas bela negara tersebut. Dalam koridor tersebut maka penulis memberikan saran hal-hal sebagai berikut:

1. Kampus menjunjung tinggi nilai-nilai akademisi; pendidikan, penelitian, dan pengabdian kepada masyarakat oleh karena itu bela negara tidak hanya terpaku pada domain tertentu saja tetapi meliputi keseluruhan dari nilai-nilai akademisi. STABN Sriwijaya Tangerang Banten sebagai salah satu perguruan tinggi hendaknya menerapkan konsepsi bela 
negara secara dinamis selain pola yang sudah diuraikan sebelumnya, seperti; workshop bela negara, mengikuti jambore atau pelatihan bela negara, madding atau jurnal ilmiah tentang bela negara atau kegiatan serupa lainnya yang merepresentasikan wujud bela negara.

2. Mahasiswa selaku agent of change secara nyata mengedepankan sikap nasionalisme yang kongkrit dengan terlibat secara aktif dan konsisten dalam wujud bela negara sebagaimana disebutkan di atas, yang tidak hanya dibatasi oleh ruang dan tempat yang ada di kampus semata tetapi juga di tempat-tempat lainnya, seperti rumah, kost, asrama, dan mall.

\section{Daftar Pustaka}

Abidah, Sitti. 2010. "Implementasi Bela Negara Melalui Resimen Mahasiswa". Cikumsworldll.blogspot.co.id. 25 November 2016.

Bahri, Efri S. 2013. Hari-hari Mahasiswa: Kiprah dan Agenda Pergerakan Mahasiswa. Jakarta: FAM Publishing.

Basrie, Chaidir. 1998. Bela Negara: Implementasi dan Pengembangannya: Penjabaran Pasal 30 UUD 1945. Jakarta: Penerbit Universitas Indonesia.

Departemen Pendidikan Nasional. 2003. Kamus Besar Bahasa Indonesia. Jakarta: Balai Pustaka.

Rianto, Subandi. Dkk. 2012. Mahasiswa: Menggagas Kebangkitan Indonesia. Surabaya: BEM Universitas Airlangga.

Subagyo, Agus. 2015. Bela Negara: Peluang dan Tantangan di Era Globalisasi. Yogyakarta: Graha Ilmu.

Sumarsono, S. et.al. 2001. Pendidikan Kewarganegaraan. Jakarta: Gramedia Pustaka Utama. 